\title{
توظيف القيم الجمالية للون الأحهر في الأعمال النحتية الحديثة
}

إعداد

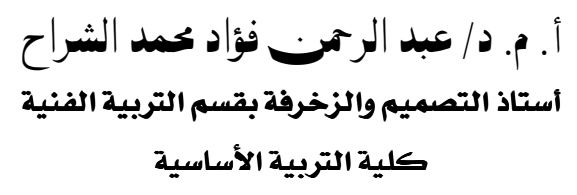

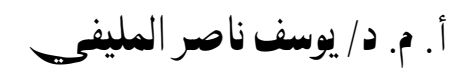

أستاذ النحت المساعد بقسم التربية الفنية

بكلية التربية الأساسية

مجلة بحوث التربية النوعية ـ جامعة المنصورة

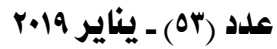




\title{
توظيف القيم الجمالية للون الأحمر في الأعمال النمتية المديثة
}

\author{
إعداد \\ أ . م . د /عبد الرحمفؤاد محمد الشراح \\ أ. م. ـ د /يوسفناصر المليفيــ
}

يحتل اللون مكانة هامـة يِّ جميع أوجـه نشاطنا، وقد اهتم الفنانون وعلماء الطبيعة وعلم المبم

النفس وغيرهم بنواحي اللون المختلفة.

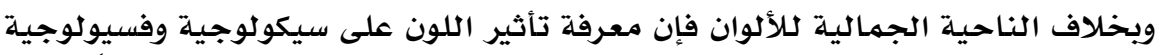

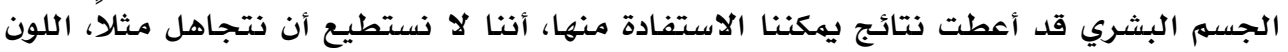

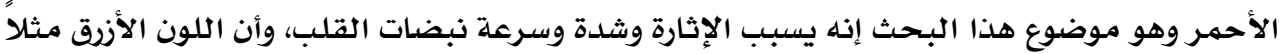
لون مهدئ للجهاز العصبي، وعليه فقد تفهم الألوان والتنبؤ بتأثيراتها .

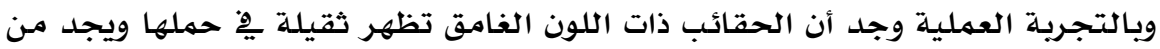

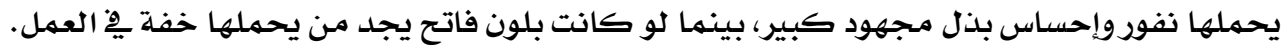

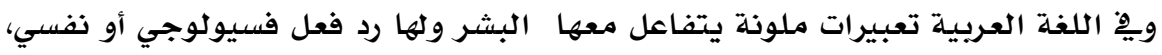

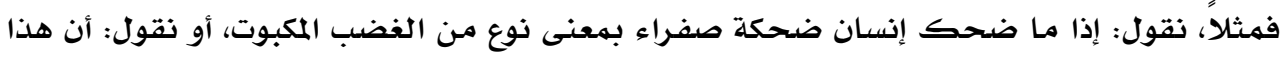

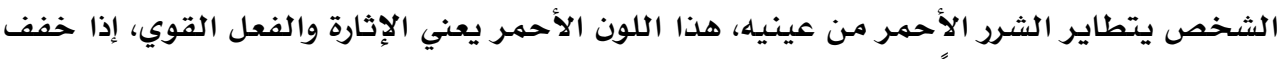

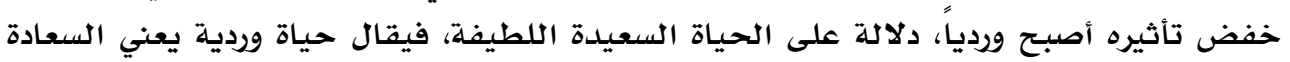
والاتزان هِِ العين.

وِِّ هذا البحث نؤكد على أن الدراسـة النظرية للألوان ليس المقصود بها حذف إحساسات

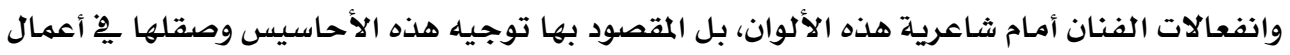

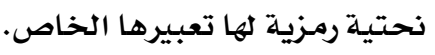

وقد برهن الفنانون بأعمالهم أن المعرفة الدقيقة للقوانين العلمية للضوء والألوان وغيرها،

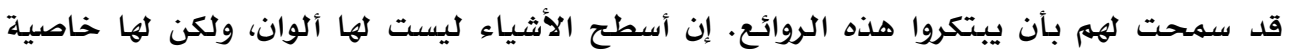

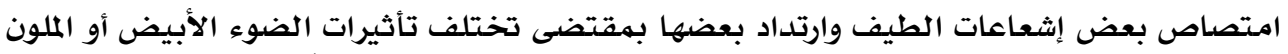

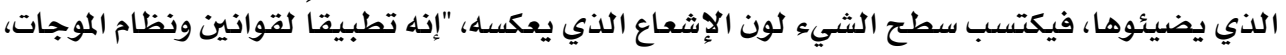

أستاذ النحت المساعد بقسه التربية الفنية - بكلية التربية الأساسية

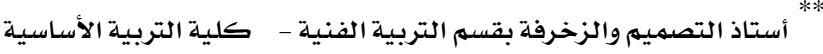


هذه الإشعاعات اللونية المختلفة تؤثر يف العين بنفس الطريقة تقريباً التي تردد وتصل بها موجات

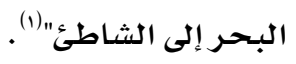

ونظرية الموجات هذه علمتنا أن الموجات ثلاثة أنواع موجات طولية ومتوسطة وقصيرة،

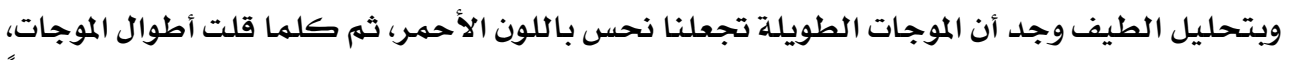
فإن جهازنا البصري يحس بالتوالي باللون البرتقالي ثم الأصفر ثم الأخضر ثم الأزرق وأخيراً البنفسجي.

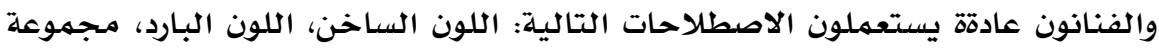

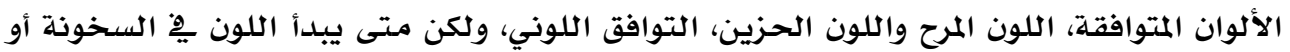

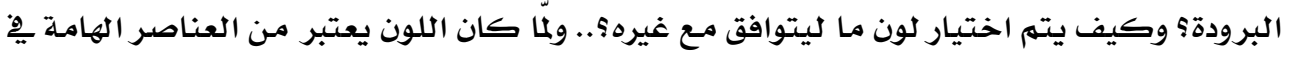

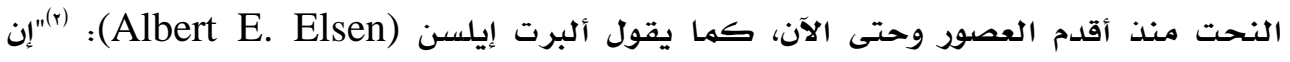

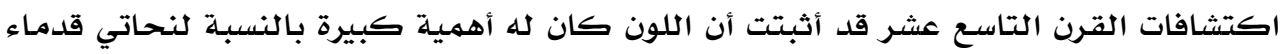

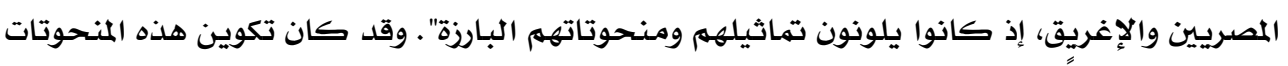

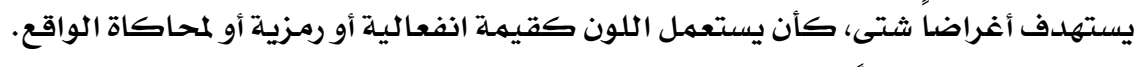

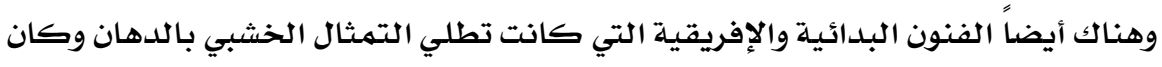

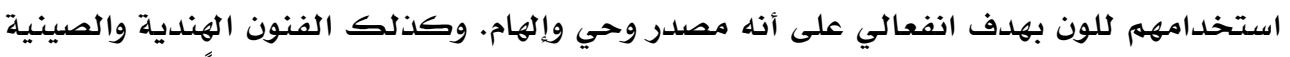

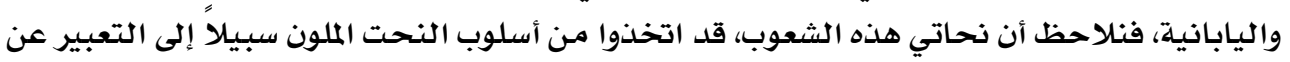
فلسفاتهم الروحية.

وعلى هذا نجد أن النحت منذ القدم عرف توظيف اللون، إما لأغراض رمزية أو لمحاكاة الواقع. ولما كان الاتجاه الأكاديهي ضد توظيف اللون ِِّ النحت، فقد ظهر التهرد على قواعد

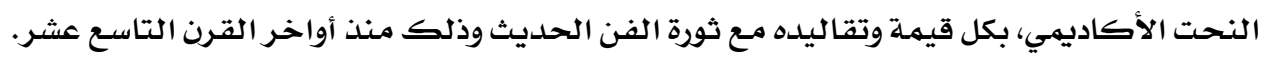

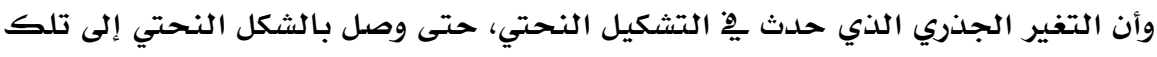

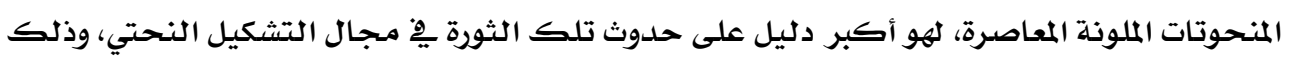

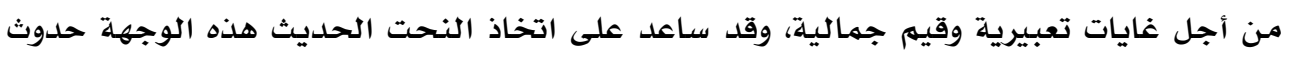

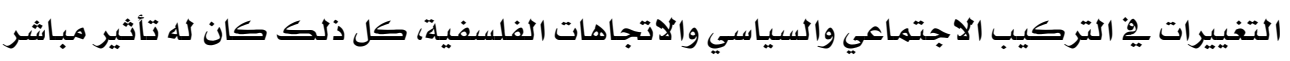

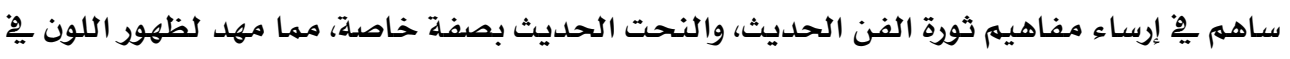
النحت الحديث.

(') يحيى حمودة: نظرية اللون، دار المعارف، القاهرة، PV9 ام، صه.

( ${ }^{2}$ ) Albert E. Elsen: Origins of modern sculpture, Pioneers \& Premises, New York, 1973, P. 102. 


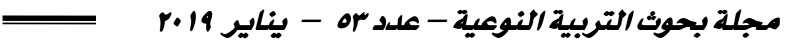

ومـع بداية القرن العشرين طالعنا النحاتون الحديثون بأعمال نحتية ملونة مثل (ليبشتز

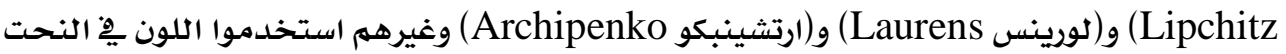

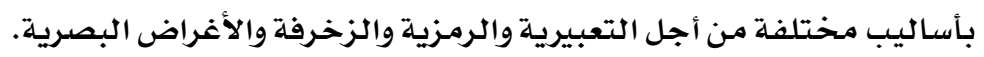

ويظهر توظيف اللون كإحدى ظواهر التعبير العريضة، حيث يستخدم النحات اللون

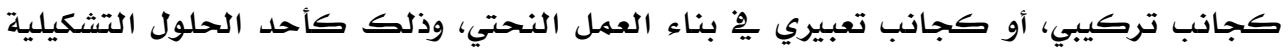

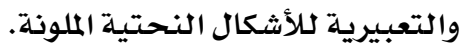

وقد لاحظ الباحث أن توظيف اللون يمثل ظاهرة منتشرة بين فناني القرن العشرين

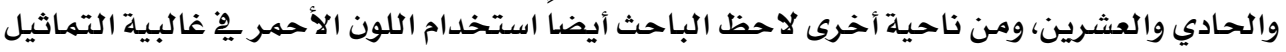

الميدانية.

1- محاولة التعرف على توظيف اللون الأحمر ِِّ النحت الحديث بجانبيه التركيبي

والتعبيري، وذلك كأحد الحلول التشكيلية والتعبيرية للنحت الحديث.

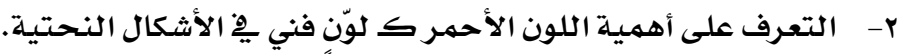

ا- ما هي علاقة اللون الأحمر كوسيلة للتعبير النحتي؟

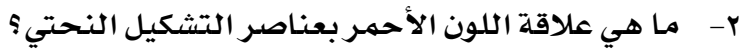

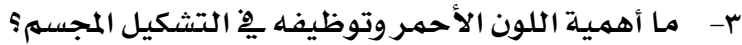

- زمنياً منحوتات القرن العشرين والحادي والعشرين يِ أوروبا وأمريكا.

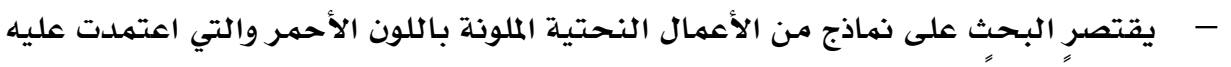
اعتمادا كليا.

أهميبة البحث: أهنماد

- - إن رؤية النحت من خلال منظار اللون الأحمر فقط سوف يضيف إلى عناصر التشكيل المجسم رؤية جديدة.

- - تفهم العوامل التي دفعت الفنانين لتوظيف اللون الأحمر.

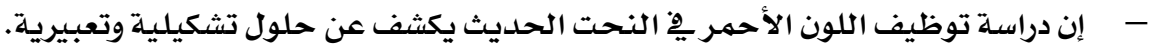

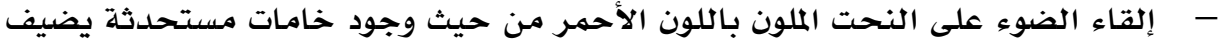

أبعاد جديدة.

هنهفج البحث:

يتبع البحث المنهج التاريخي والوصفي والتحليلي ٍِِ إجراء هذا البحث بحيث يتعرض إلى: 
ا- بعض المفاهيم الفكرية والتكنولوجية المستخدمة التي دعت النحاتين لاستخدام اللون

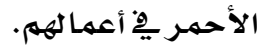

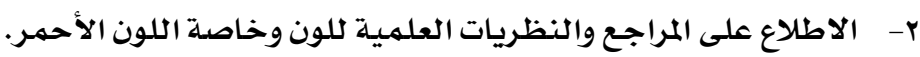

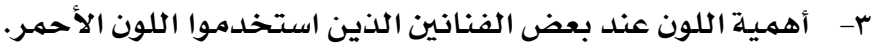

ع- عرض تحليلي لبعض رواد النحت مستخدمي الندئ بعض اللون الأحمر.

أهم هصطاتحات البمث:

"كلمة (لون) يطلقها الفنانون التشكيليون، وكذا المشتغلون بالصباغة وعمال المطابع،

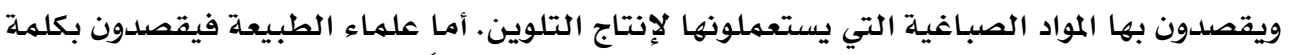

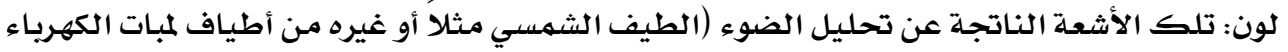

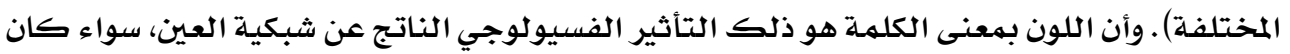

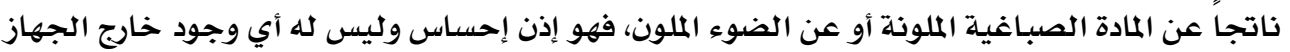

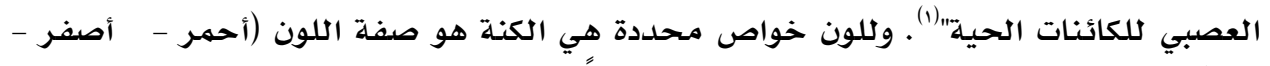

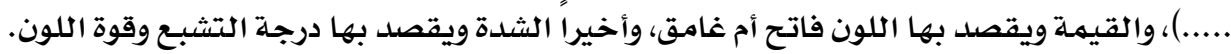

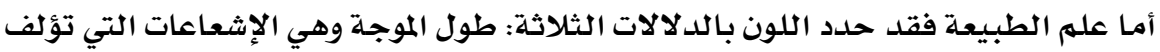

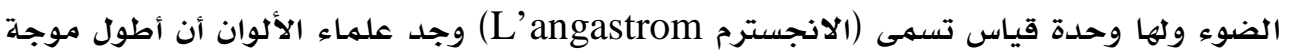

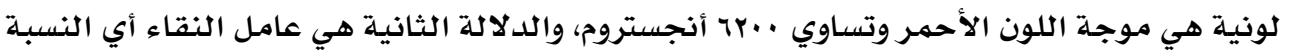

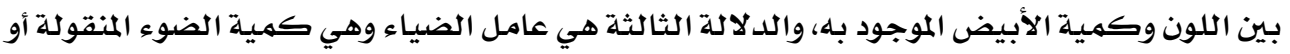

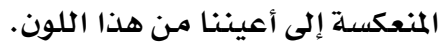

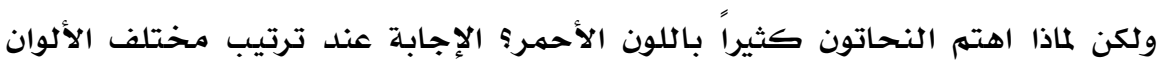

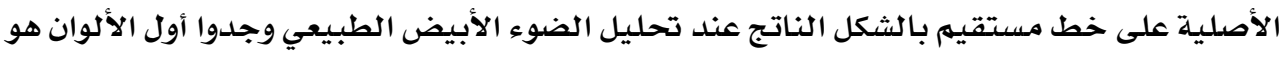

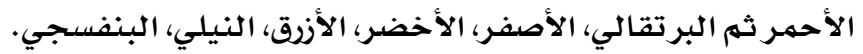

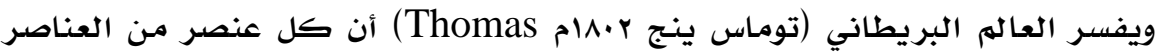

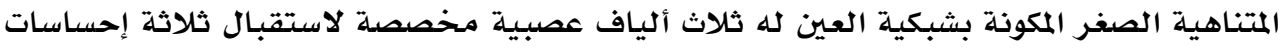

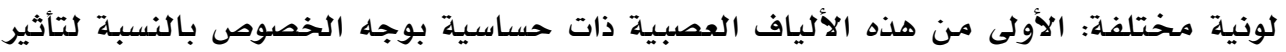

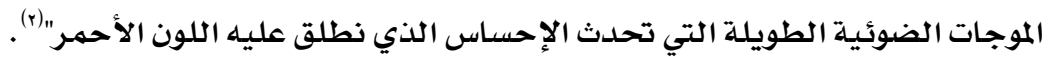
والمجموعة الثانية موجات متوسطة الطول ونطلق عليها اللون الأخضر، والمجموعة الثالثة

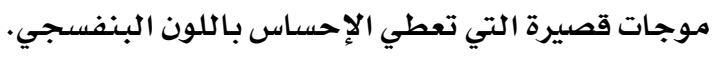
ونتيجة لذلك فإن اللون الأحمر يؤثر بقوة على المجموعة الأولى والمجموعتين الآخرتين وإن

كان بقوة أقل.

(') (') يحيى حمودة: مرجـع سبق ذكره، صـم.

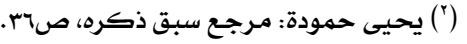




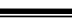

واللون الأحمر من مجموعة الألوان الساخنة (الدافئة) هي ألوان مصدر للحرارة والدفء والسخونة.

واللون يرتبط بتأثيرات ثلاث: تأثيرات ذات قيمـة تشكيلية تختص ببحث الزوايا التي تتعلق

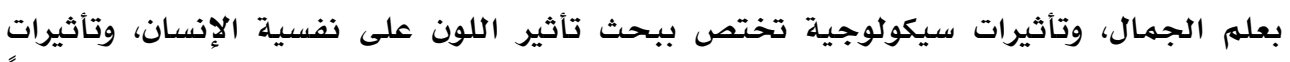

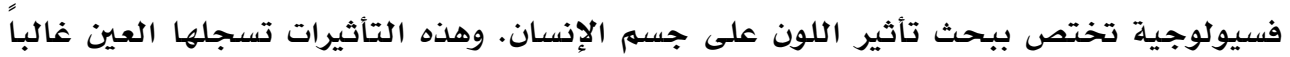

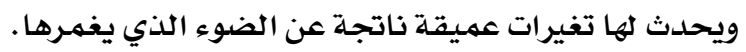
وقد حددت (ليونوركنت Leonork Keat) قوة تأثير بعض الألوان فقالت: "اللون الأحمر،

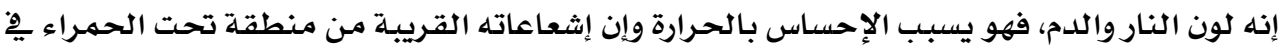

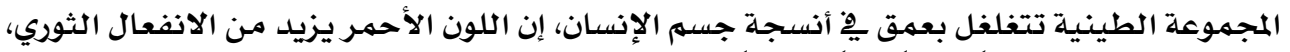

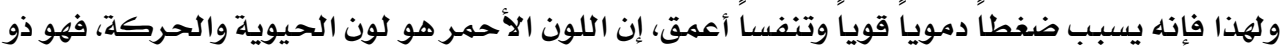

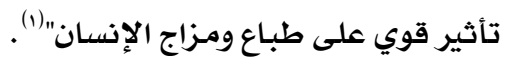

بينما ذكر (مارتن لانج Martin Lang) ِِّ تحليل الشخصية عن طريق اللون والخواص

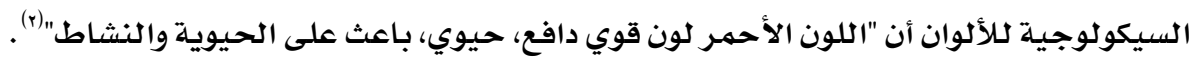

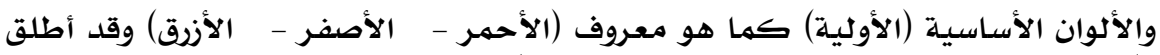

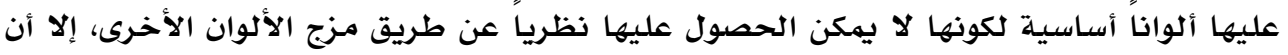

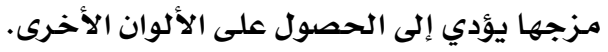

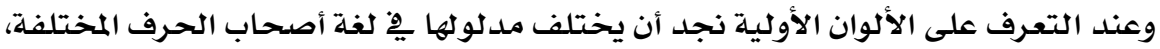

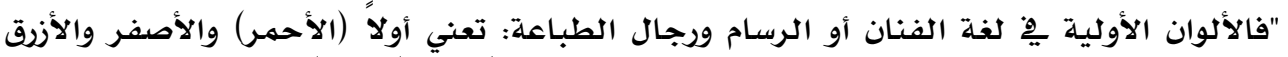

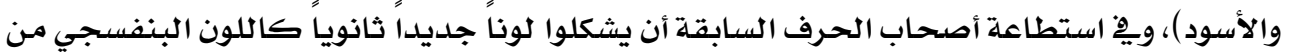

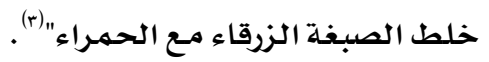
والألوان الأولية ِِّ لغة عامـة الناس هي (الأبيض والأسود و(الأحمر) والأصفر والأخضر الأحراء والأزرق) ويطلق على هذه المجموعة اسم الألوان الأولية السيكولوجية الألوية.

"والألوان الأولية ِِّ لغة المصورين الفوتوغرافيين أو السينمائيين ورجال العلوم الطبيعية:

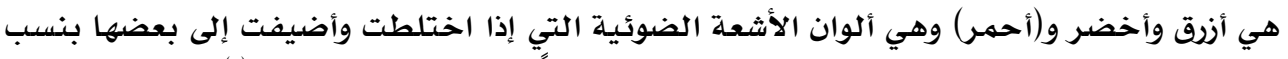

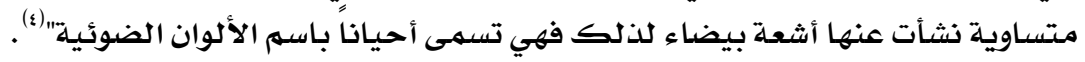

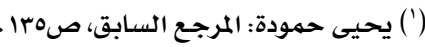

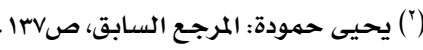

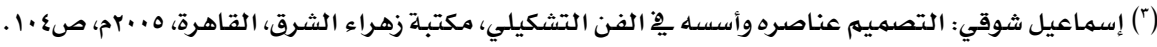

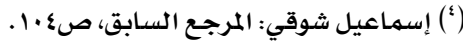


وهناك تأثير ديناميكي، إذ نجد عندما نقارن بين ألوان دافئة وأخرى باردة أن اللون الدافئ

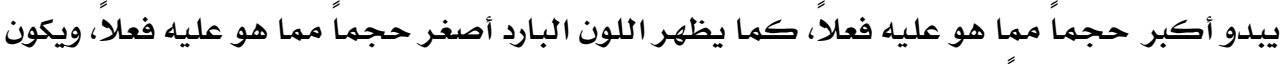
الخداع البصري أخّاذا.

"كما إن هناك تأثيراً ديناميكياً آخر خاصدة بتآلفات درجة الحرارة وتباينات درجة الحرارة،

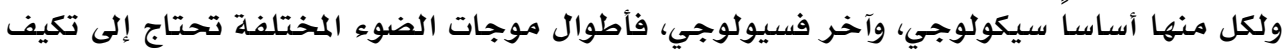

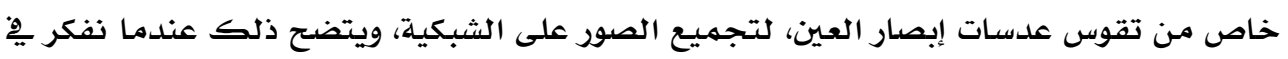

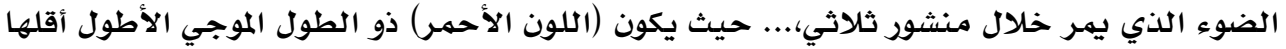

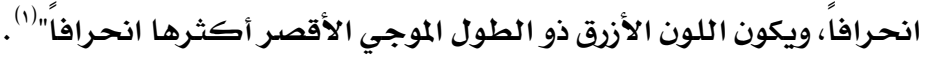

ومن أوائل النحاتين الذين استخدموا اللون يِّ بداية القرن العشرين هو الفنان (ليبشتز)

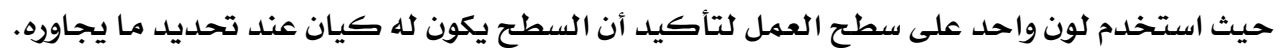
وقد ذكر (ليبشتز) أنه عندما قدم إلى باريس كانت فكرته عن النحت أنه كله أبيض وهات

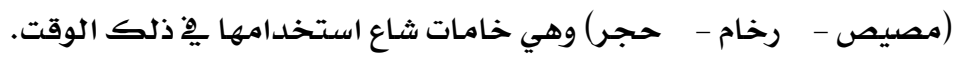

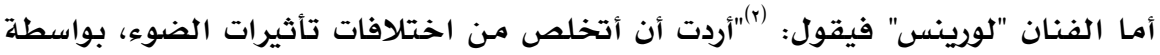

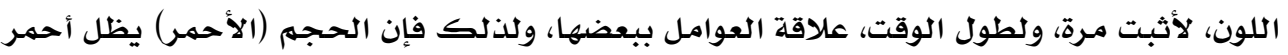

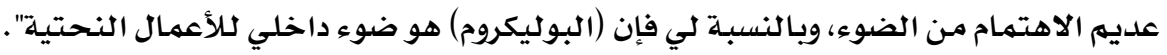

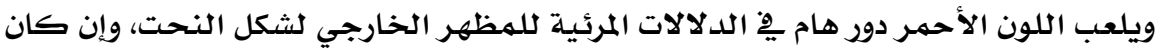

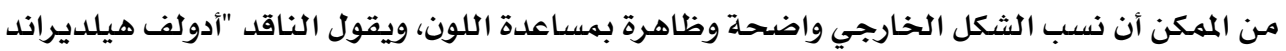

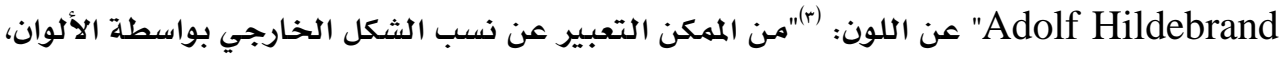

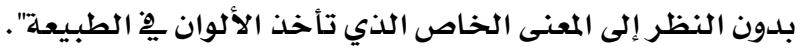

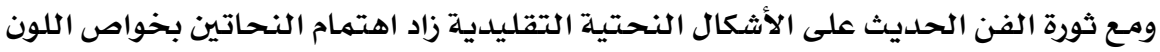

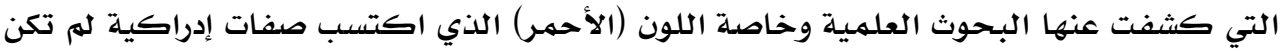

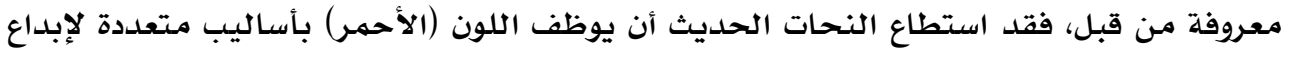

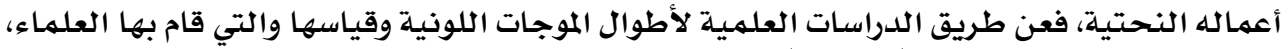

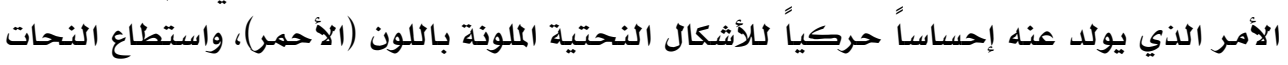

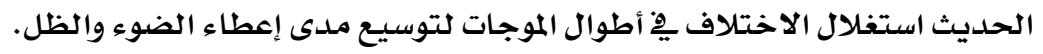

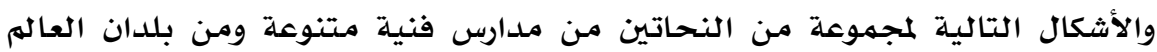

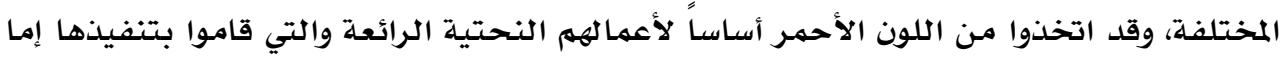

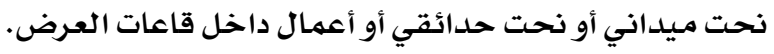

(') روبرت جيلام سكوت: أسس التصميم، ترجمهة عبد الباقي محمد إبراهيم، دار نهضة مصر، القاهرة، •191 م، ص19 . Albert E. Elson: Ibid, P. 106. $\left({ }^{2}\right)$ Adolf Hildebrand: The problem of form in sculpture, Stechert, New York, 1907, P. 78. $\left({ }^{3}\right)$ 


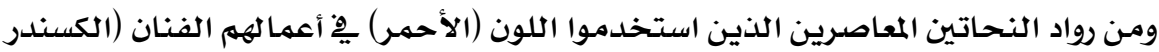
كالد Alexander Calder) الذي نفذ أعمال كبيرة للعرض خارج المباني وهي تعتبر من الأعمال

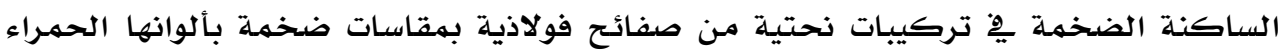

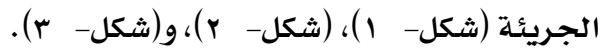

ويأتي الفنان (كلاس أولدنبيرج Claes Oldenburg) ليقدم لنا روائع من أعماله

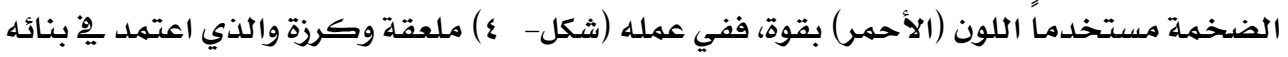

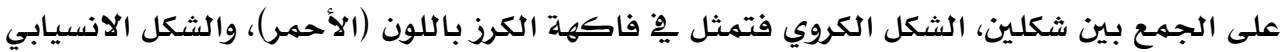

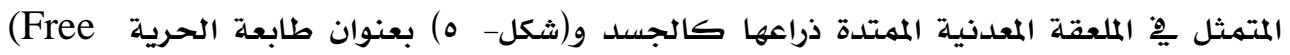

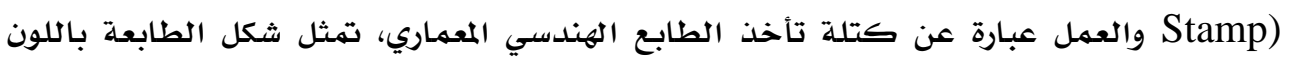
(الأحمر) متركزة على الأرض، وقد تم وضع كلمة (Free) فِّ مكان الطباعة باللون (الأحمر).

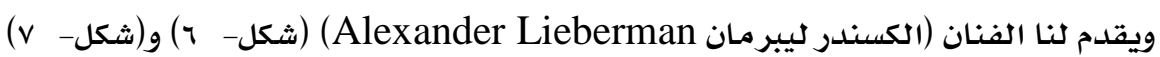

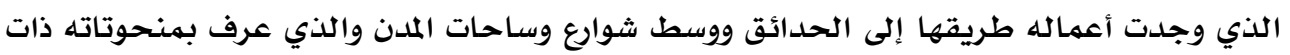

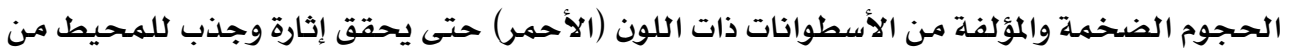
حوله.

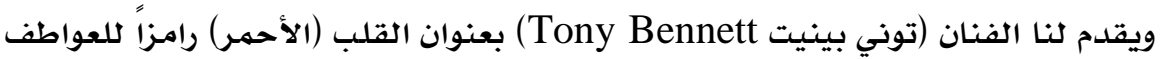
الجياشة وكله نبض وقد صنع منه أكثر من نسخة وضعت يِّ بلدان كثيرة (شكل- م ب) باللون

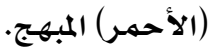

(شكل- ه) للفنان تشو يونج، زهرته اللوتس (الحمراء) التي تنتمي للنحت المتحرك ليعطي

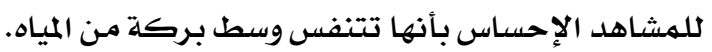
أما (شكل- •إ) للمثال (روبرت انديانا) وعملة الحب الذي جسهم الحروف الأربعة باللون

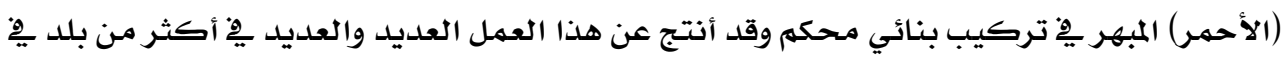
العالم.

وِِْ عمل من الأعمال العظيمة قدم لنا الفنان الياباني (أسامو نوجوشي) عمله (شكل-

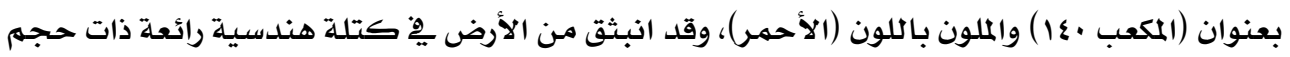
كبير.

$$
\text { و(شكل- r r ) قدم لنا الفنان (لي اسكيلب) عمله الرائع باللون الأحمر. }
$$

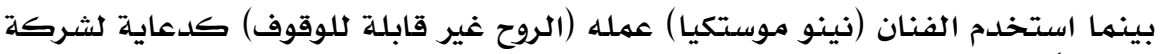

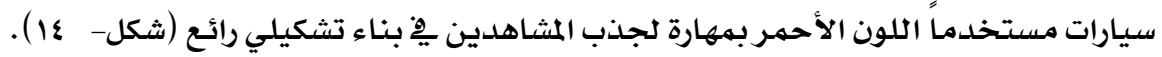
أما الفنان (روبرت هيلر) وعمله (ثكل- 10) وهو من الأعمال الداخلية عبارة عن امـرأة

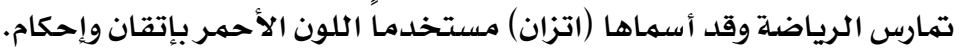




$$
\text { و(شكل- 17 ) قدم لنا الفنان (روزنتا) عمله الضخم باللون الأحمر. }
$$

و(شكل- IV) للفنان (سيلفين كونتارسكي) وهو عبارة رقم 8 وقد لون باللون الأحمر

$$
\text { وبحجم كبير يِّ أحد ميادين لندن. }
$$

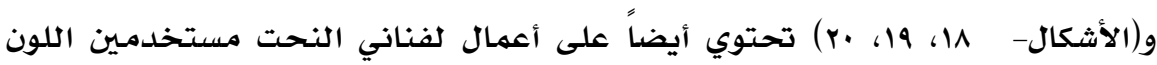

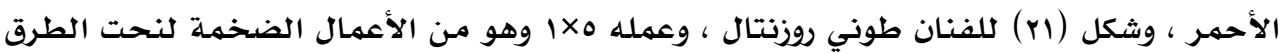

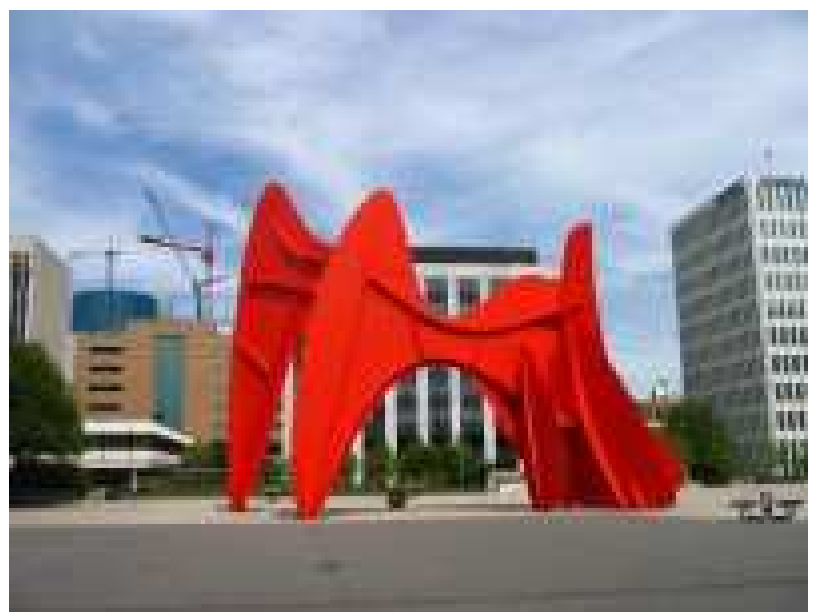

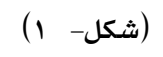

الكسندر كالدر - العنكوب الاحمر - استنلس ستيل - ملون بالأحمر

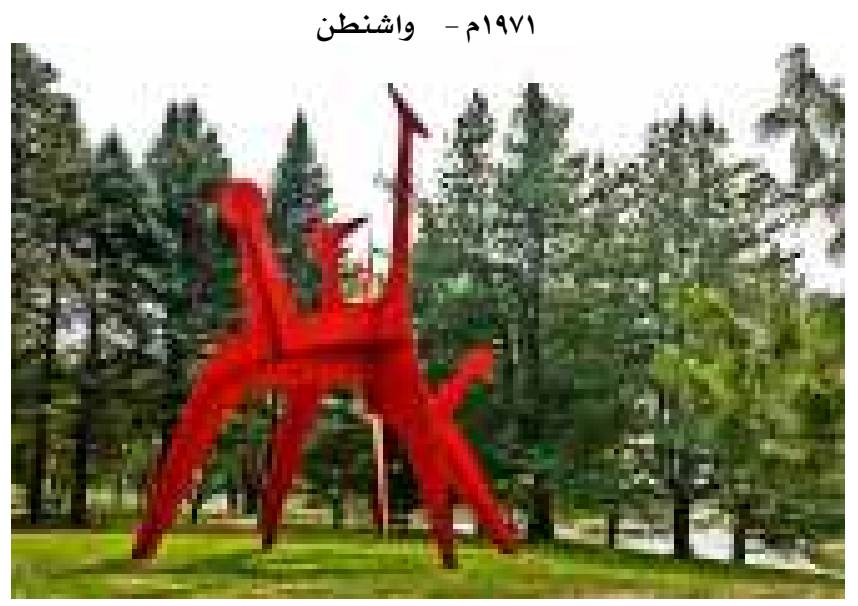

$$
\text { (ش }
$$

$$
\begin{aligned}
& \text { الكسندر كالدر - خمسة سيوف - استنلس ستيل أحمر }
\end{aligned}
$$

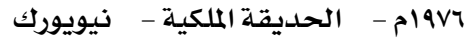




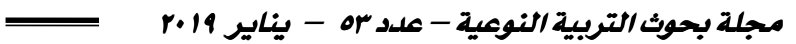

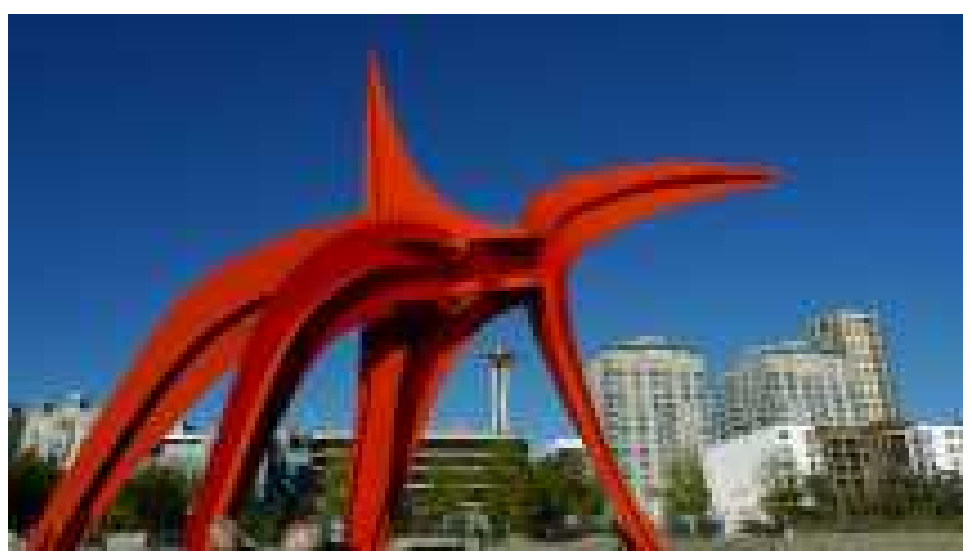

( شكل- r )

الكسندر كالدر - العنكبوت - استنلس ستيل أحمر

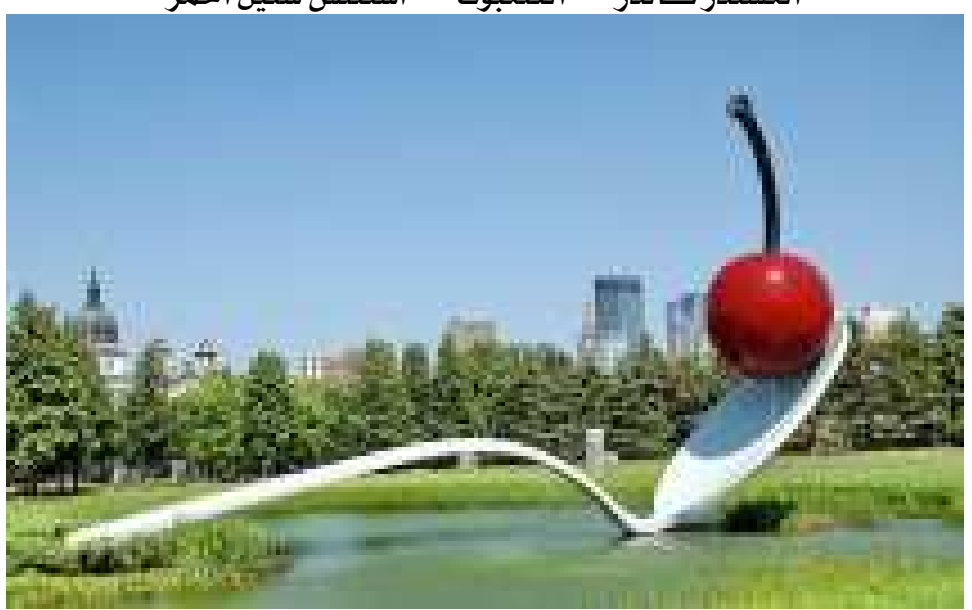

$$
\text { ( شكل- ( }
$$

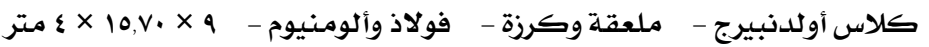

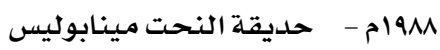




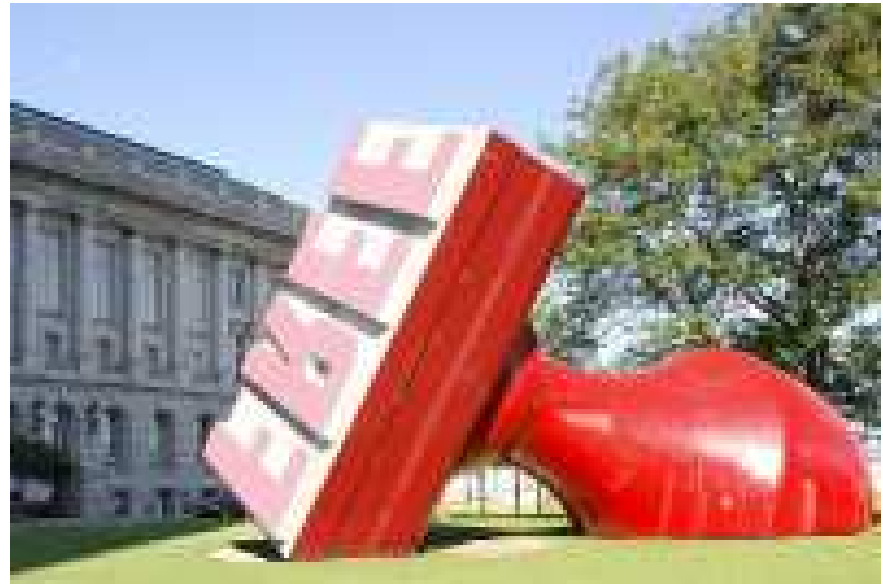

( 10 (شكل)

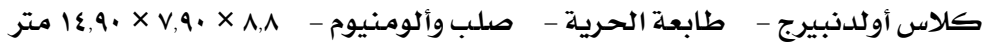
- أوهايو

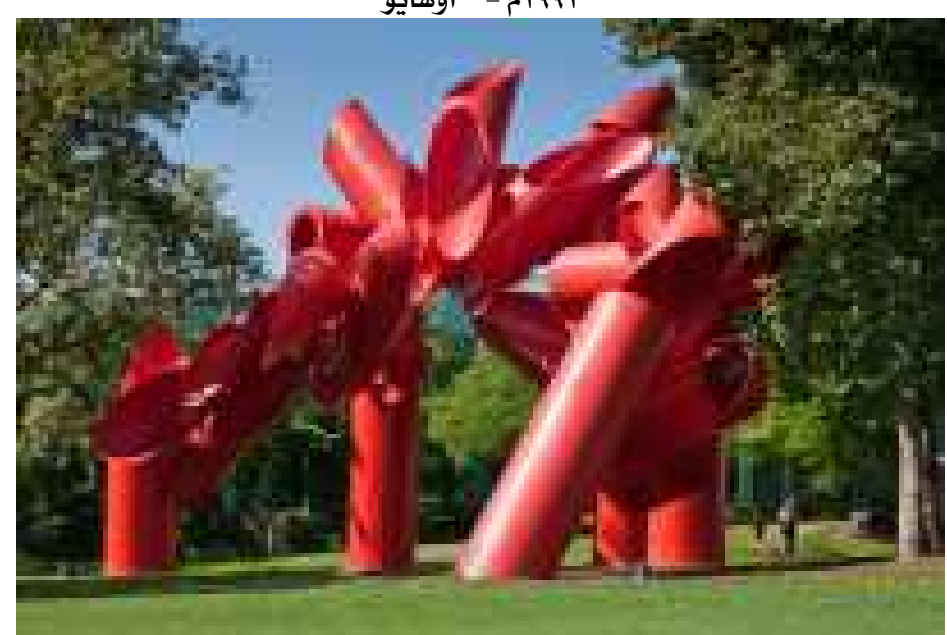

$$
\text { ( } 1 \text { ( }
$$

الكسندر ليبر مـان - إلياذة هوميروس - استتلس ستيل أحمر

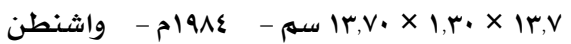




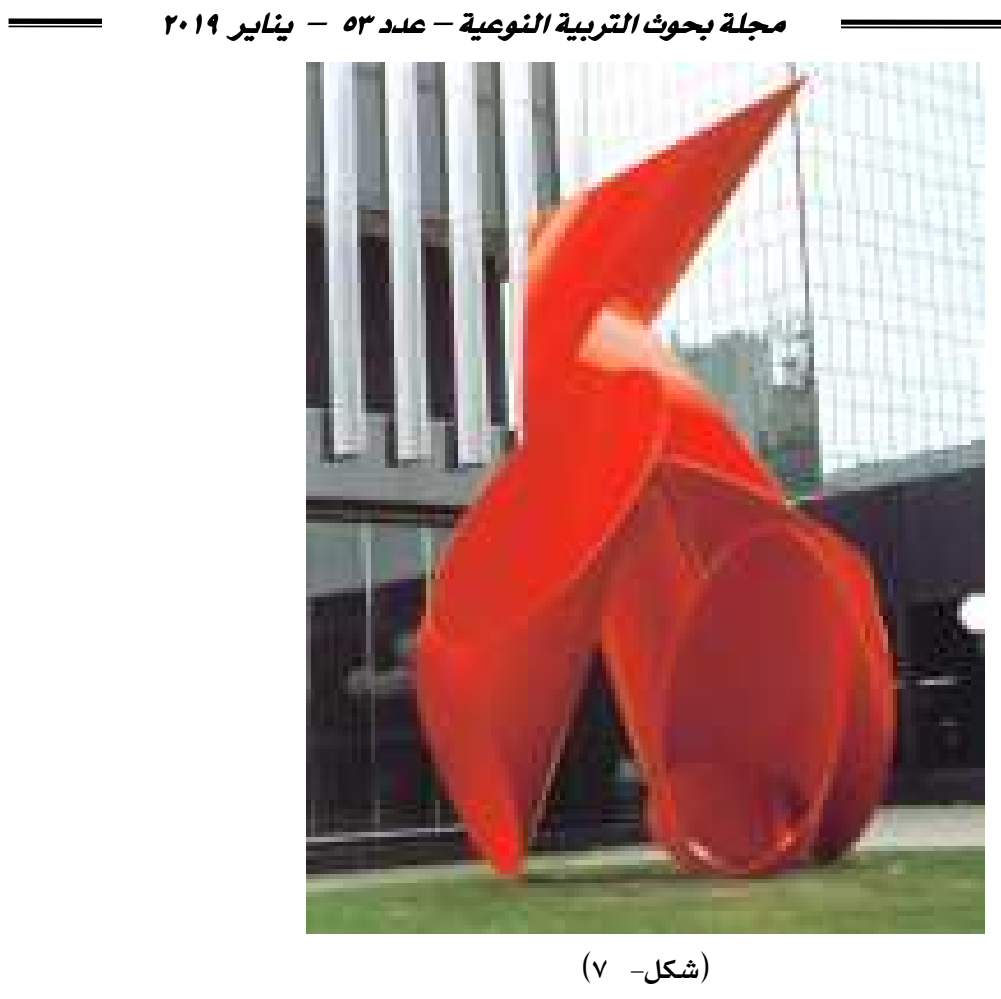

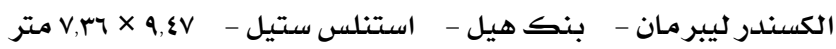

كاليفورنيا

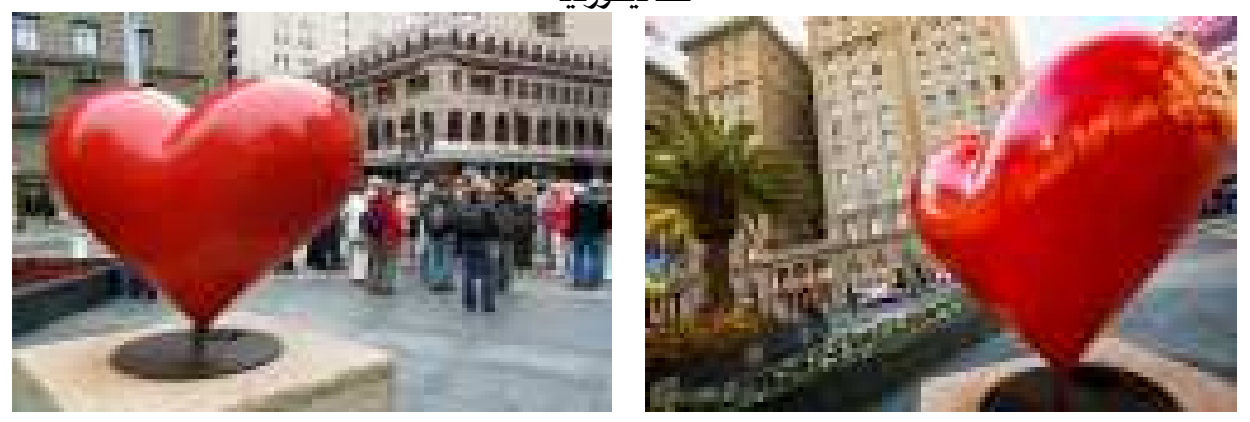

$$
\begin{aligned}
& \text { (شكل- (ش) أ ، ب } \\
& \text { توني بينيت - القلب الأحمر } \\
& \text { ميدان الوحدة - سـان فرانسيسكو }
\end{aligned}
$$




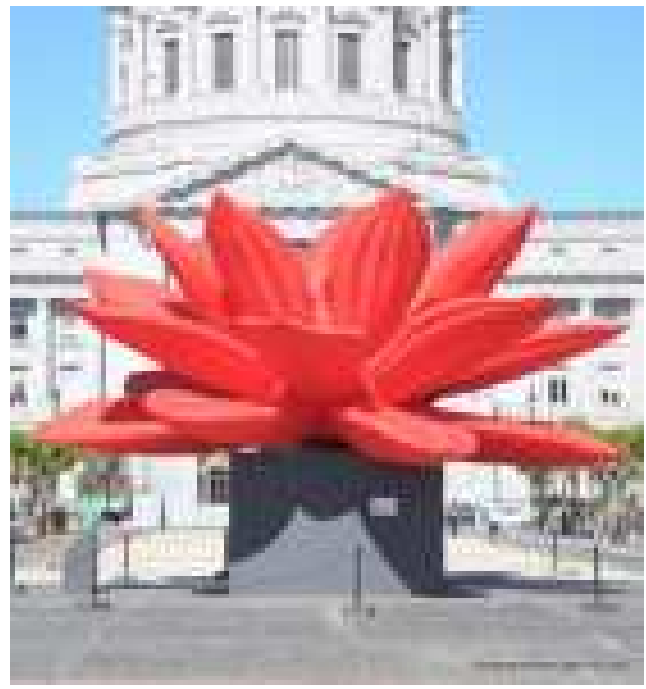

$$
\text { (4) ( }
$$

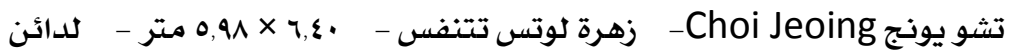

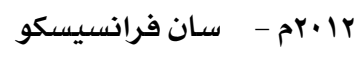

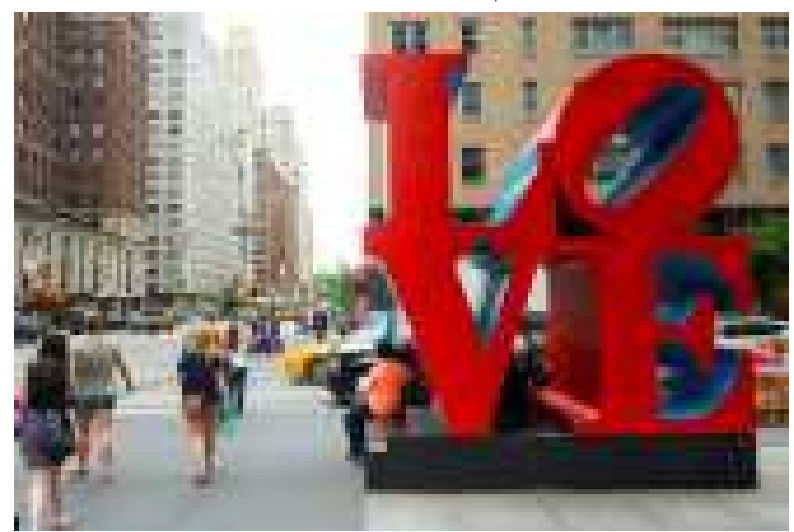

$$
\text { (1. (1) - (1) }
$$

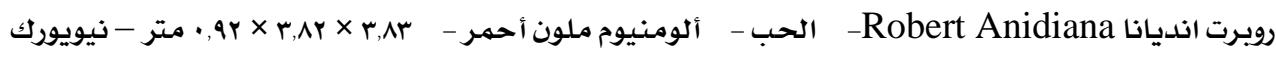

\section{v.}




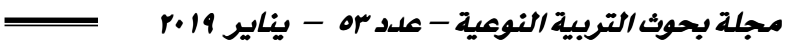

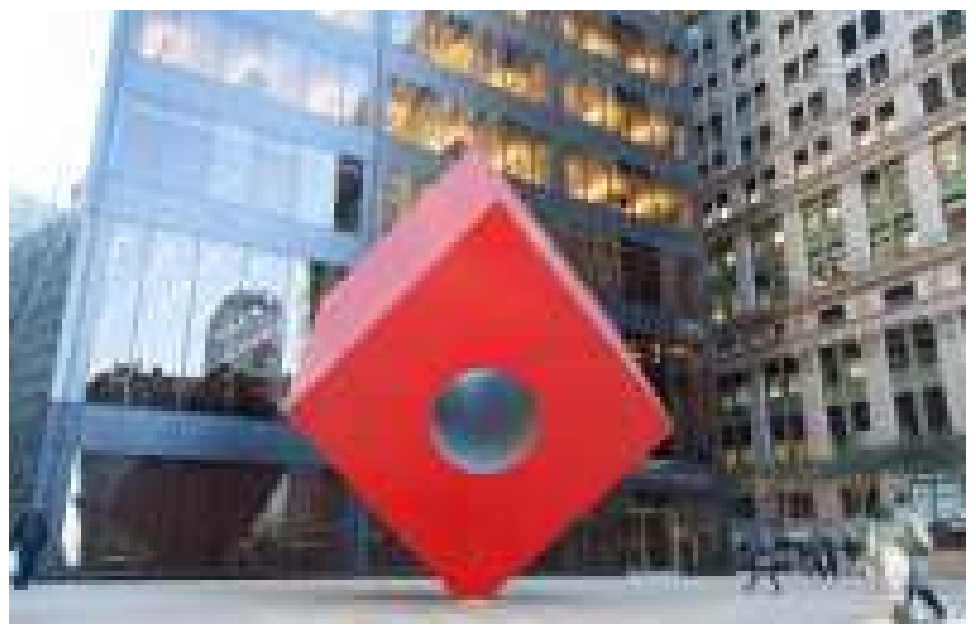

(شكل-

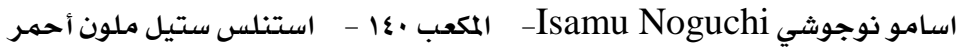

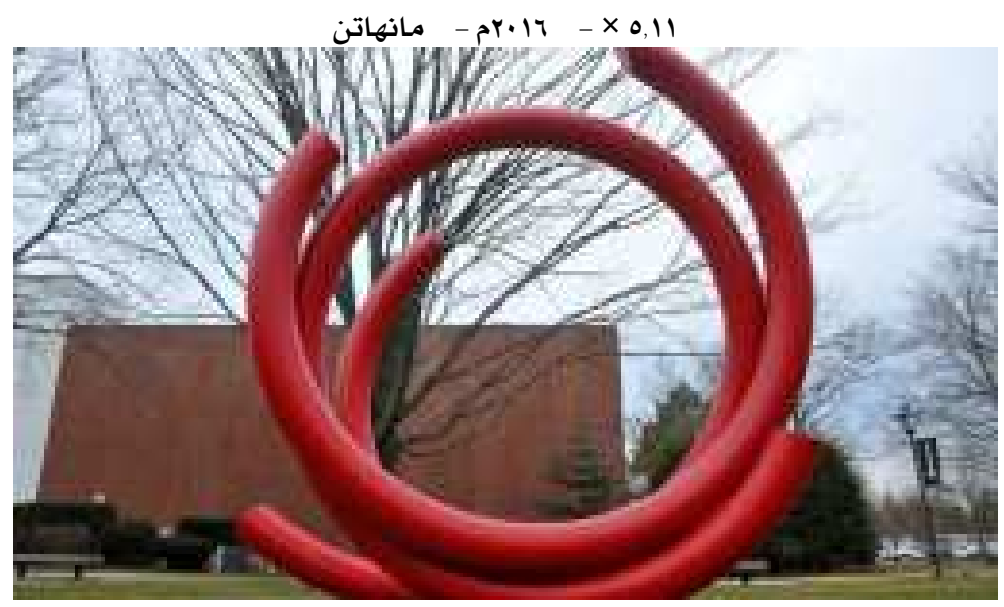

(شكل- (Ar )

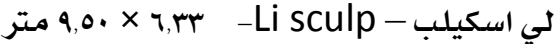

pr. Is 


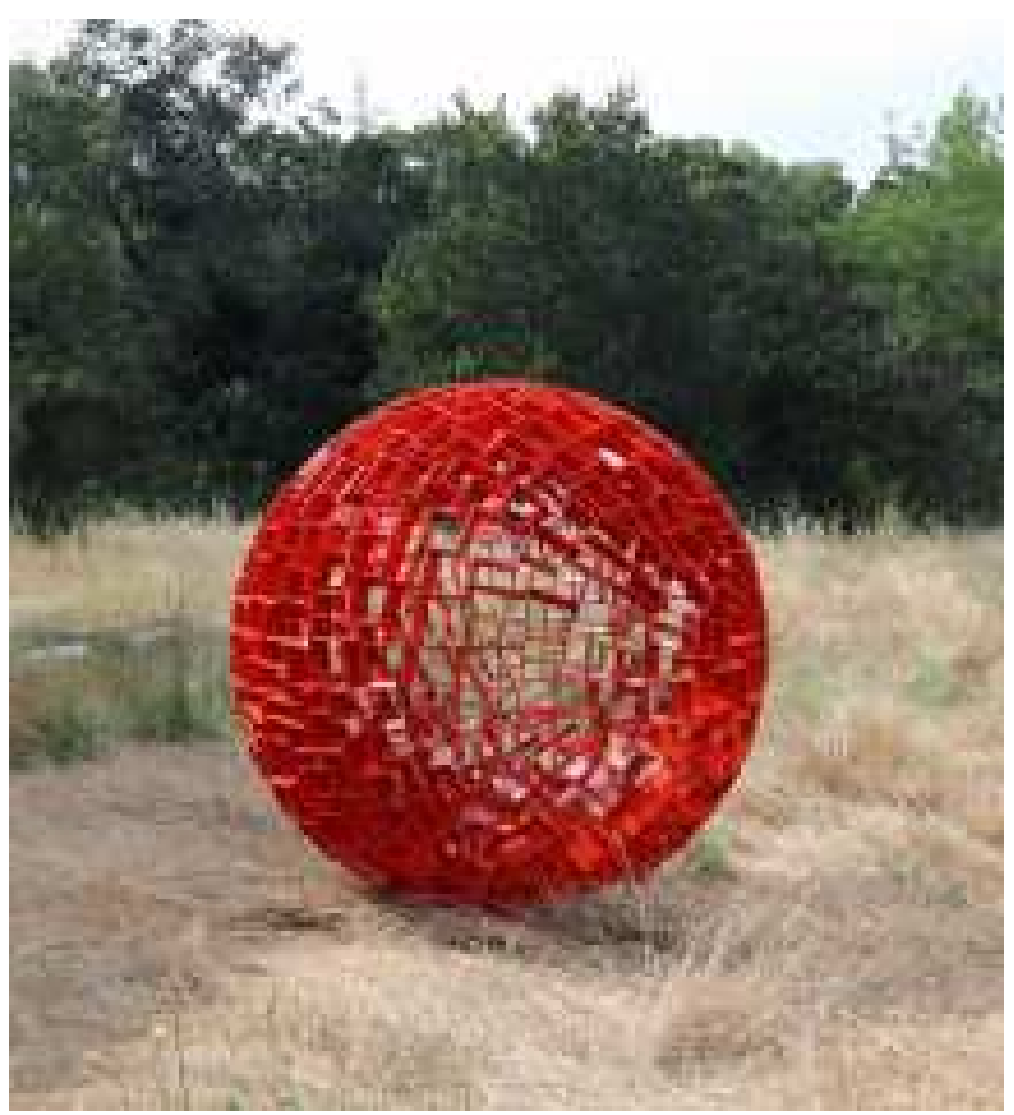

(1) (شكل)

ايفان ملكيان -Iven mcleaneen Noguchina نحت الطرق والحدائق وعمله 1×5 وهو من

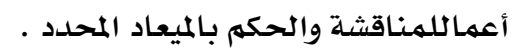

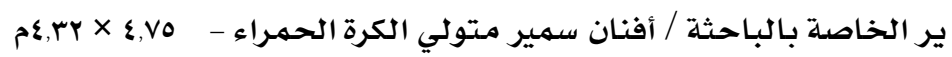
ar. 10 


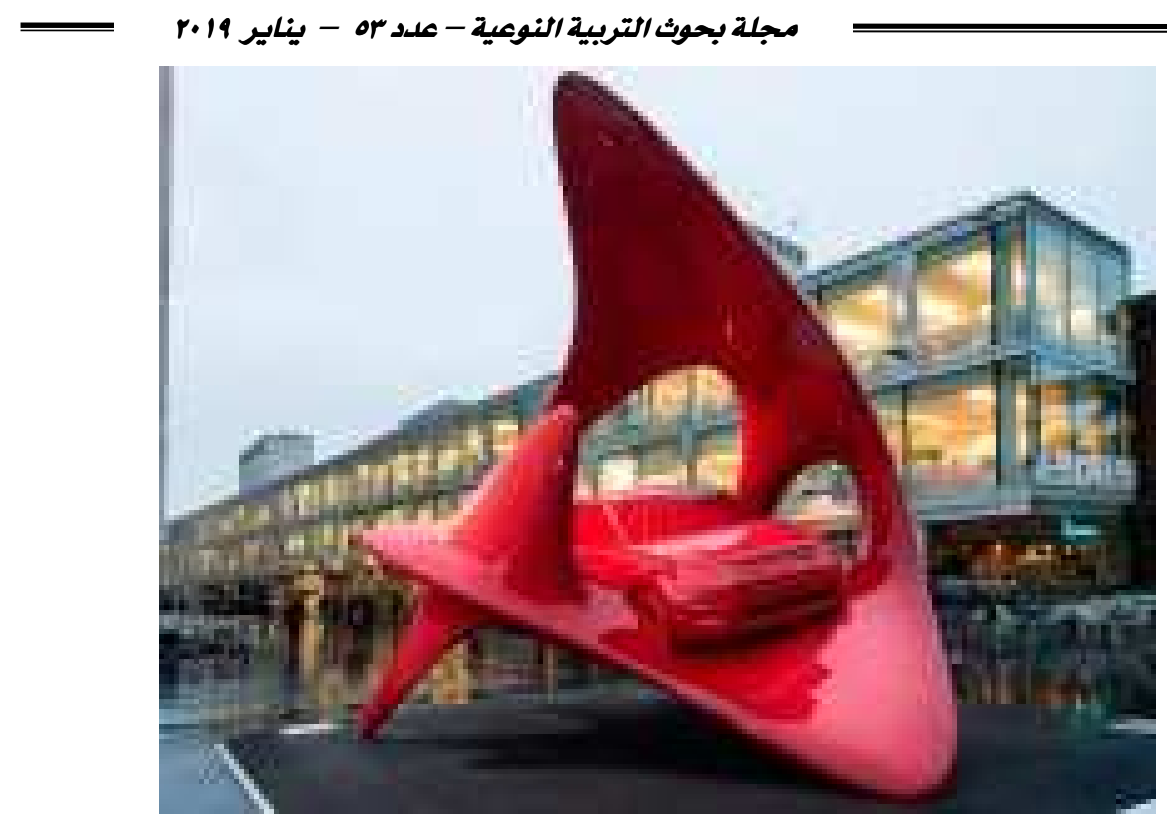

(شكل- (1)

نينو موستيكا - nino Muslica الروح الغير قابلة للوقوف - فيبر استنلس ستيل

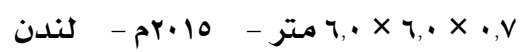

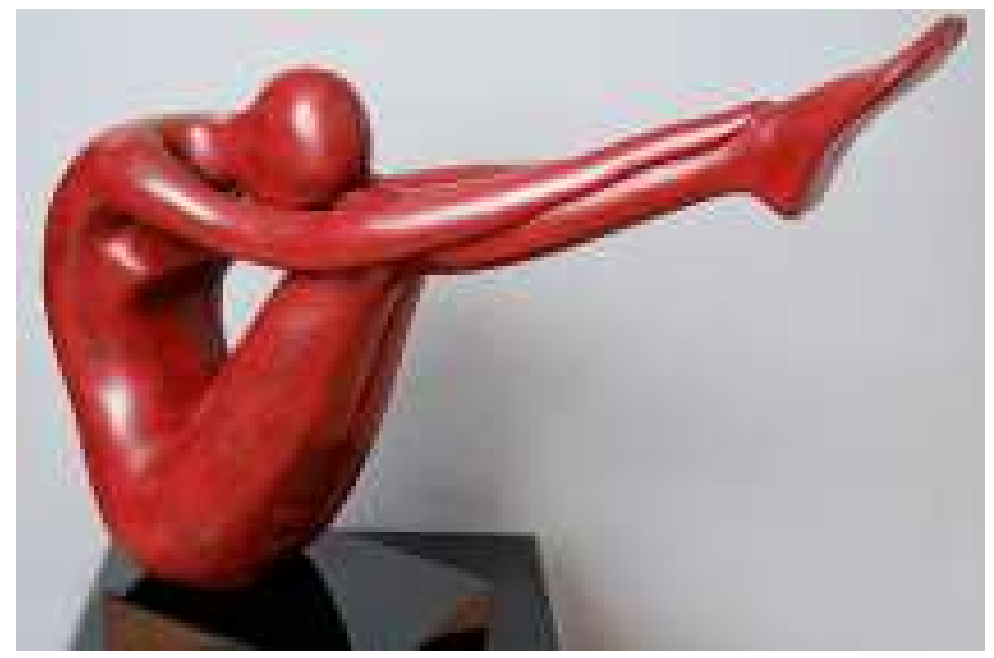

(10 (شكل)

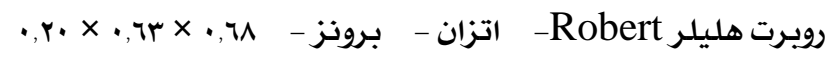

كاليفورنيا 


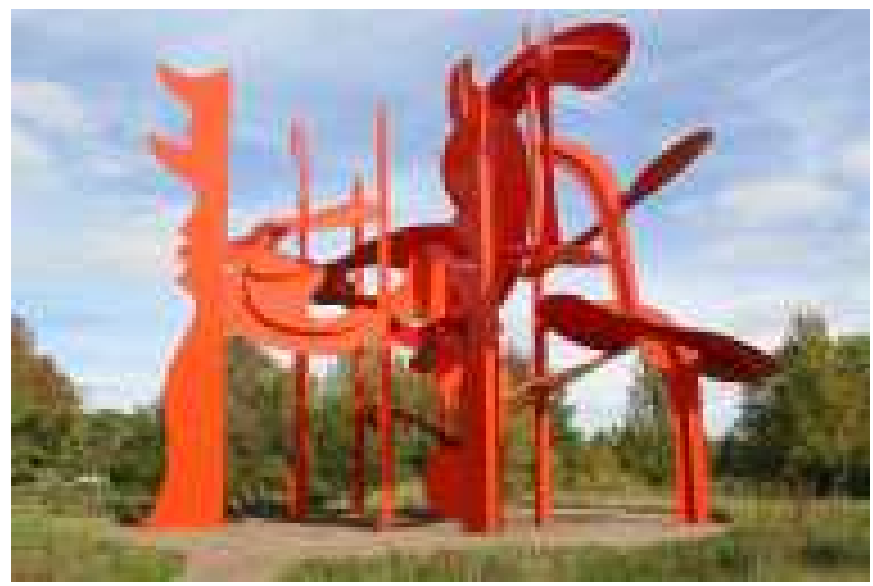

(شكل- (17)

الكسندر لبيرمان - بقايا كل شئ - استنسيل ملون ، ع×هـ متر

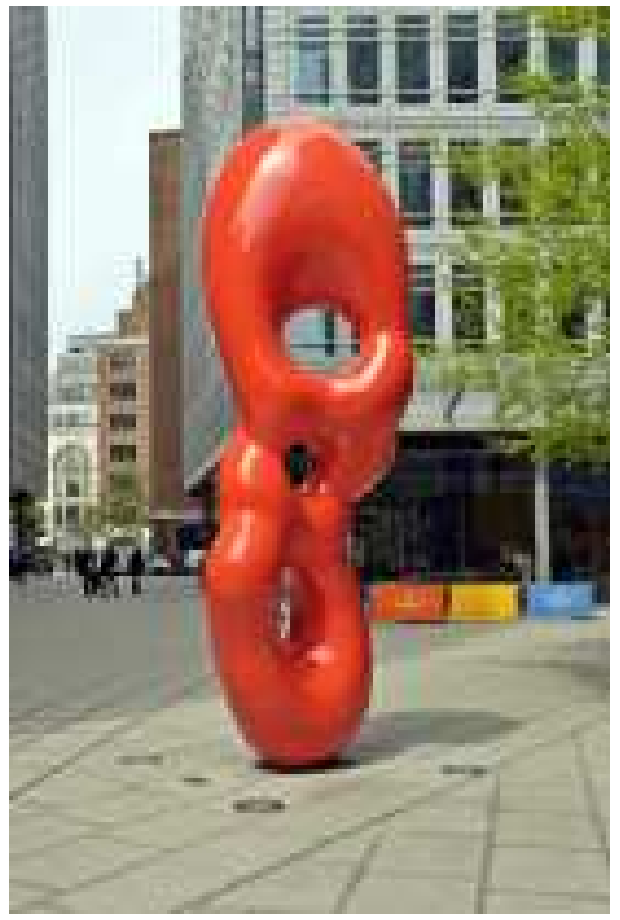

( A - (

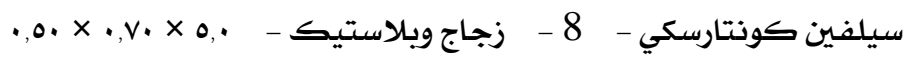

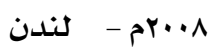




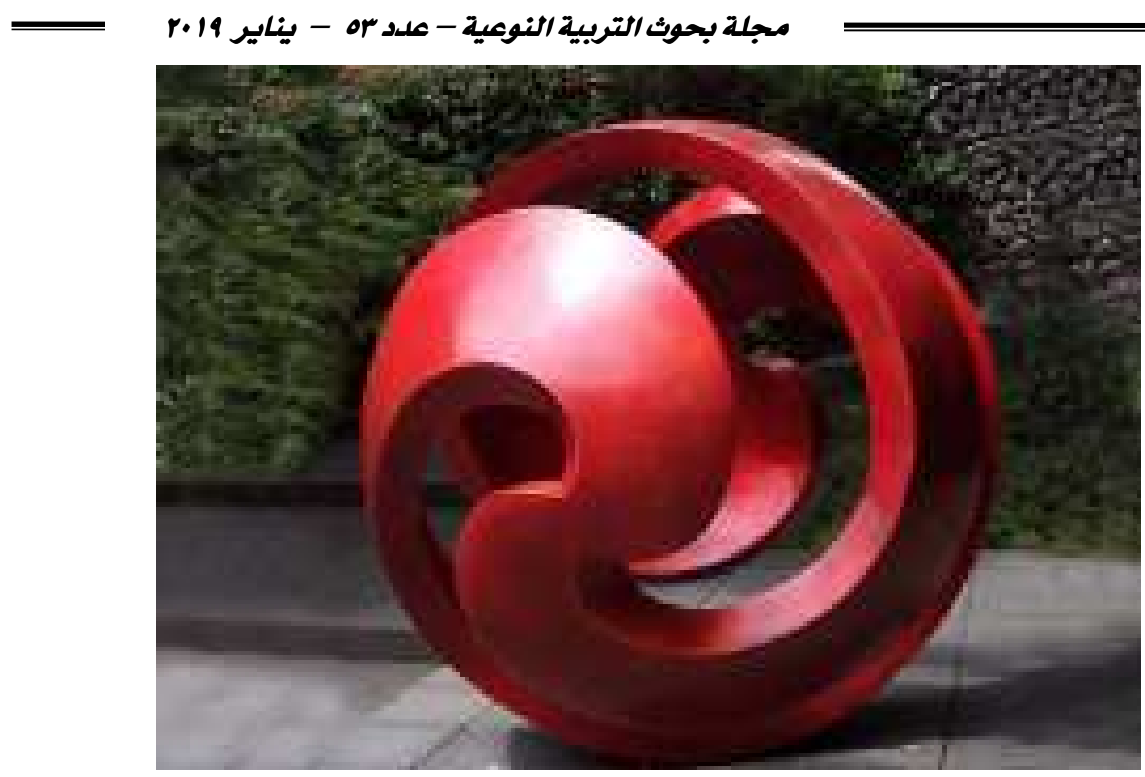

(شكل- (11 ) (11)

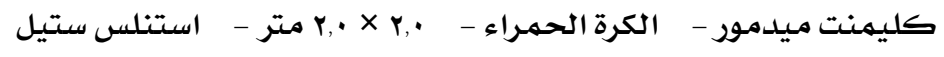

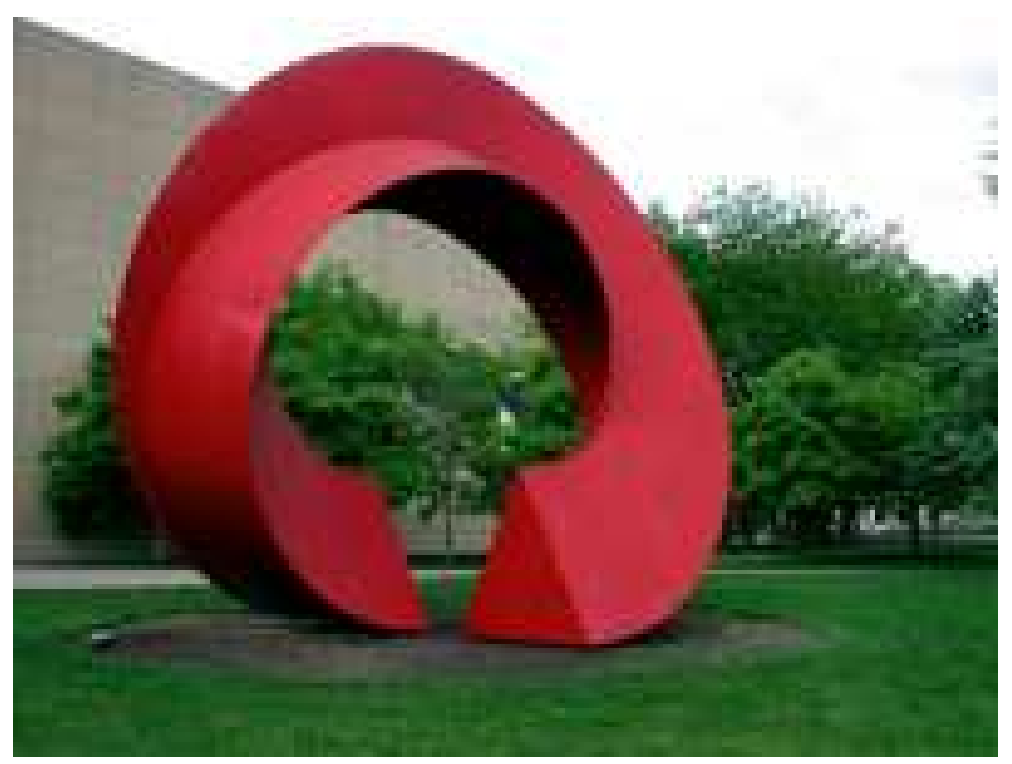

(شكل- (19)

ايفان ملكيان - كرة حمراء - استنلس ستيل 


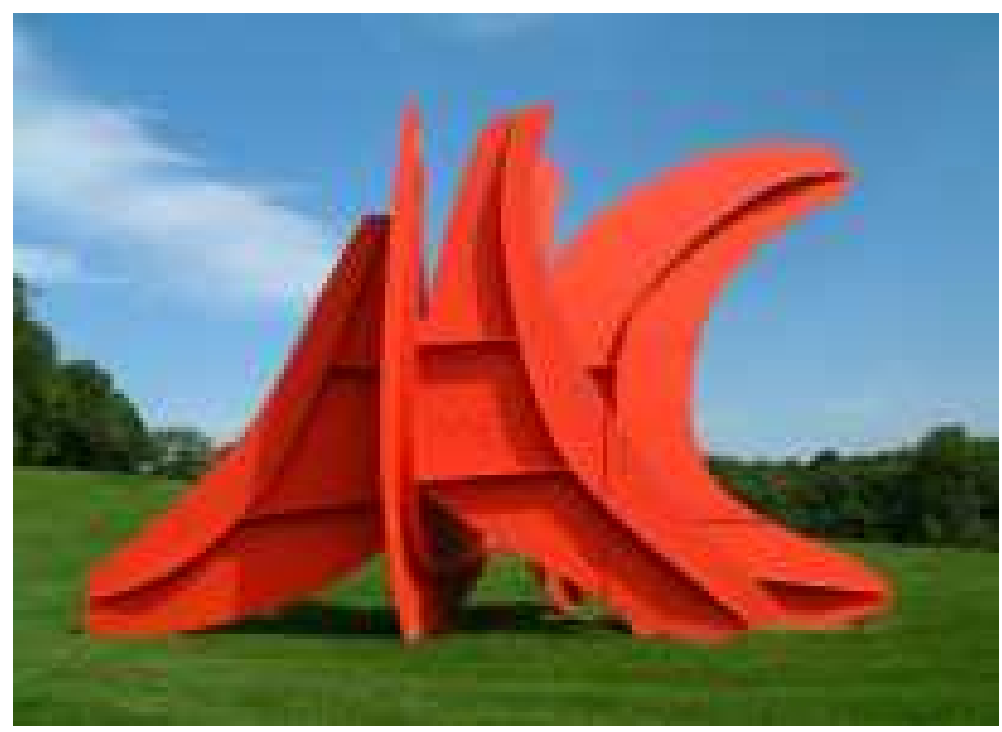

(

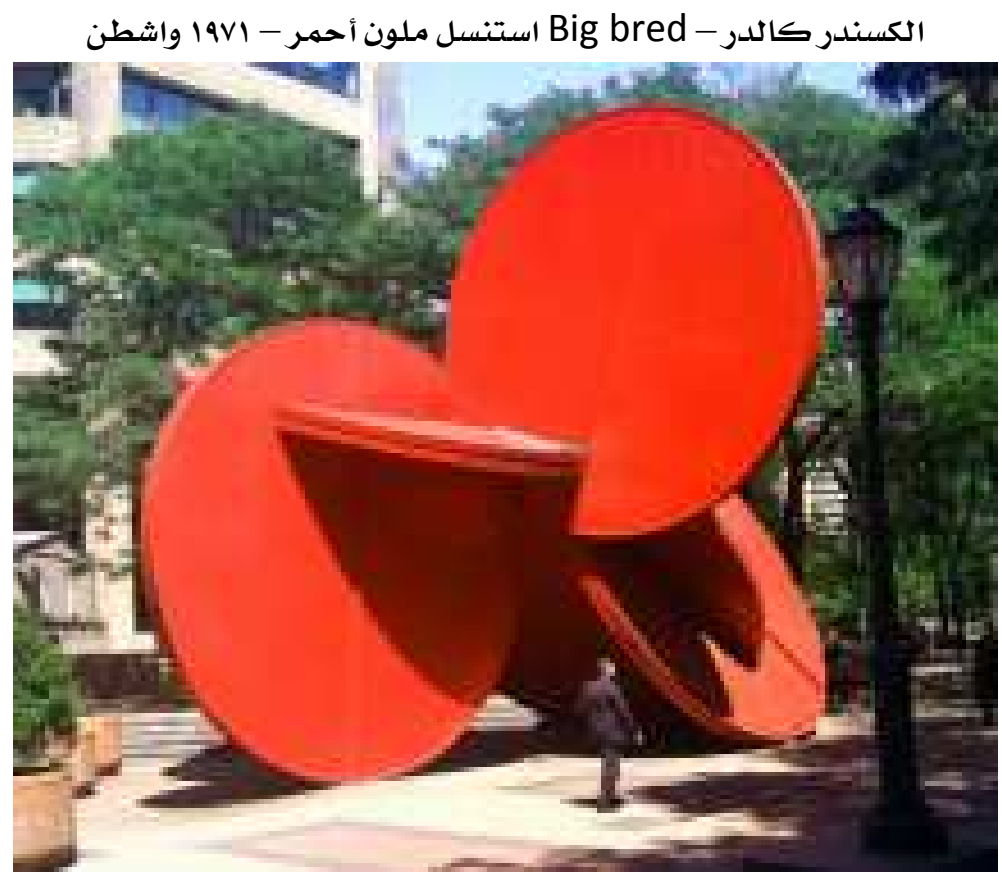

( ( شكل (

طوني روزنتال - خمسة يِّ واحد (م) (1) - نيويورك 


\section{توصيات البحث:}

1- يجب الاهتمام بتفهم أساليب توظيف اللون يِّ النحت.

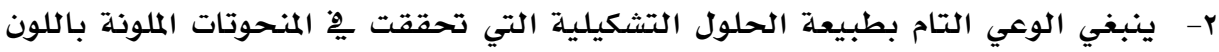

$$
\text { الأحمر وغيره من الألوان. }
$$

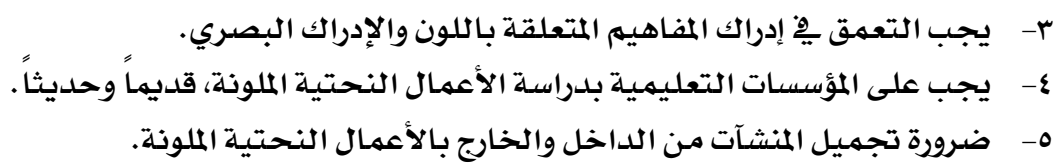

المراجع:

1) أحمد حافظ رشدان وفتح الباب عبد الحليه: التصميه، عالم الكتب، القاهرة، •Vوام.

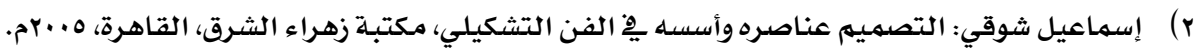

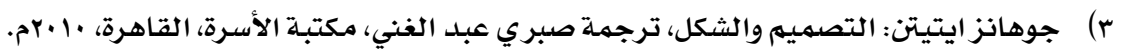

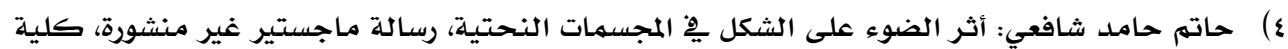

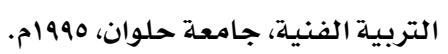

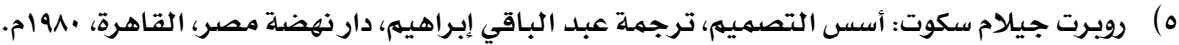

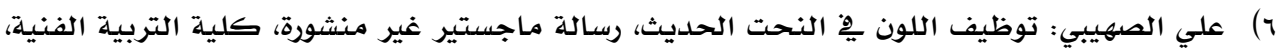

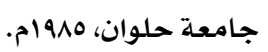

V) محيي الدين طرابية: القيه الخطية ٌِِ رسم القرن العشرين، رسالة ماجستير غير منشورة، كلية التربية

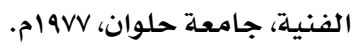

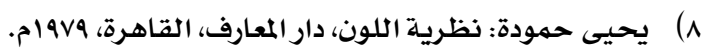

9) Albert E. Elsen: Origins of modern sculpture, Pioneers \& Premises, New York, 1973.

10) Wucius Wong: Principles of color design, New York, 1984.

11) Wucius Wong: Principles of three dimensional design, New York, 1977. 